\title{
Numerical study on the flexural behaviour of normal- and high-strength concrete beams reinforced with GFRP bar, using different amounts of transverse reinforcement
}

\author{
Mostafa Kazemi $^{1 *}$, Rahmat Madandoust ${ }^{2}$, Carlos Chastre $^{3}$, Mohammad Reza Esfahani ${ }^{4}$, Luc \\ Courard $^{5}$
}

\section{Corresponding author*}

${ }^{1}$ Ph.D. Candidate, GeMMe Building Materials, Urban and Environmental Engineering (UEE), University of Liege, Liège, Belgium, E-mail: mostafa.kazemi@uliege.be

${ }^{2}$ Full Professor, Department of Civil Engineering, University of Guilan, P.O. Box 3756, Rasht,

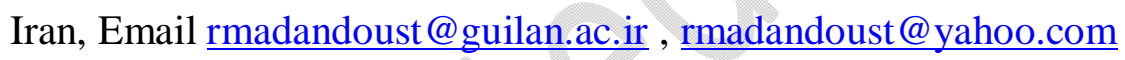

3 Associate Professor, CERIS and Department of Civil Engineering, Universidade Nova de Lisboa, 2829-516_Caparica, Portugal, Email: chastre@fct.unl.pt

${ }^{4}$ Full Professor, Faculty of Engineering, Ferdowsi University of Mashhad, Mashhad, Iran, Email: esfahani@um.ac.ir

${ }^{5}$ Full Professor, GeMMe Building Materials, Urban and Environmental Engineering (UEE), University of Liege, Liège, Belgium, Email: luc.courard@uliege.be 


\title{
Numerical study on the flexural behaviour of normal and high-strength concrete beams reinforced with GFRP bar, using different amounts of transverse reinforcement
}

\author{
Mostafa Kazemi ${ }^{1}$, Rahmat Madandoust ${ }^{2}$, Carlos Chastre $^{3}$, Mohammad Reza Esfahani ${ }^{4}$, Luc \\ Courard $^{5}$
}

\begin{abstract}
This study was numerically focused on the non-linear behaviour of glass fibre reinforced polymer (GFRP) reinforced concrete beams with different amounts of transverse reinforcement. The mid-span deflection of concrete beam cannot effectively be restricted using higher amount of flexural GFRP bars, owing to their low deformability factor. So, the use of high transverse reinforcement ratio is proposed to decrease the mid-span deflection and crack widths. Following this, the effect of reinforcement is required to carefully assess to better understand the flexural behaviour of concrete beams. The main goal of this study was to numerically evaluate the mid-span deflection, stress distribution and failure mechanism of normal- and high-strength concrete beams with low and high flexural reinforcement ratios (GFRP bar) and different amounts of transverse reinforcement using finite element (FE) analysis. The results revealed a fair agreement between the developed FE models and experimental beams. Besides, the mean value of experimental-to-predicted load ratio was 0.96 , with average coefficient of variation of $2.69 \%$. Moreover, the truss action mechanism generated the diagonal compression in the cracked concrete and tension in the transverse reinforcement, resulted in decreasing the mid-span deflection. In addition, for all specimens with and without transverse reinforcement, the highest stress intensities were observed in the bottom of concrete component at service load. However, by increasing the load from service to ultimate, the use of transverse reinforcement caused to propagate some parts of high stress intensities near to the sides of concrete component. Furthermore, the presence of the transverse reinforcement resulted in distributing the stress intensity in the normal-strength concrete beams more than that in the high-strength concrete beams either at service load or at ultimate load.
\end{abstract}

Keywords: GFRP bars, Fiber reinforced plastics, Concrete beams, Transverse reinforcement, Finite element analysis, Flexural behaviour, Shear behaviour. 


\section{Introduction}

Concrete is one of the most popular construction materials and it has high compressive strength and low tensile strength [1-7]. So, when cracking dominates concrete behaviour, one of the solutions is to use reinforcements such as longitudinal bars and stirrups to enhance the tensile and shear resistance of concrete members [8-10]. Longitudinal steel bars, embedded in concrete elements, are known for their ability to improve the tensile strength capacity and partially shear strength. However, the corrosion of steel bars is one of the main types of damage on reinforced concrete members [11-13] and it seems that coating of the steel bars cannot be considered as a cost-effective solution to increase the resistance to the salty and marine environment. In recent years, a number of research studies on the durability behaviour of FRP-to-concrete interfaces exposed to dry/wet cycles and salt fog cycles with salt water [13], temperature cycles [14] and elevated service temperatures [15] have been regarded by researchers. Considering the good performance of FRP to environmental actions, some alternative reinforcing materials such as glass fibre reinforced polymer (GFRP) bars with suitable resistance to the alkaline and corrosive environment have been introduced to achieve the intended tensile features of reinforced concrete elements [16-18]. As per a study by Ashour [19], diagonal cracks have appeared in GFRP reinforced concrete beams with no transverse reinforcement at ultimate load and the results showed that failure modes of all specimens have occurred due to shear. The effect of flexural GFRP bars on crack widths of concrete beams was evaluated by Ospina and Bakis [20]. The results showed that the crack widths decreased by increasing the amount of flexural GFRP bars. A reduction in the tensile strength of GFRP bars, embedded in concrete members was observed by Najafabadi et al. [21], once the bar diameter decreased and the temperature increased.

The bond behaviour of GFRP bars and steel bars in self-compacting concrete was compared to each other by Golafshani et al. [22]. The results revealed that the bond behaviour of steel bars was better than that of GFRP bars. The bond quality of GFRP bars in the normal-strength concrete beam was compared with that in a self-compacting concrete beam by Zemour et al. [23]. According to the results, the load-bearing capacity, failure mechanism, and crack pattern of GFRP bars in self-compacting concrete beam were found to be nearly the same in normalstrength concrete. Meanwhile, the GFRP bars' bond strength in normal-concrete beams was moderately higher than that in self-compacting concrete beams. Recently, Saleh et al. [24] 
evaluated the GFRP bars' bond quality in high-strength concrete beams. The results revealed that the top bars' bond strength was lower than that of the bottom bars.

The mid-span deflection and crack widths of concrete beams can be controlled using a higher amount of flexural GFRP bars [25], but the failure mode of these types of reinforced concrete elements is found to be brittle owing to their low deformability factor [26,27]. So, the maximum amount of longitudinal GFRP bars is required to be restricted to prevent the occurrence of brittle failure mode in reinforced concrete members as reported by Newhook et al. [28]. As an alternative solution, the use of high transverse reinforcement ratio is proposed to enhance the deformability of reinforced concrete beams and decrease the deflection and crack widths. Concerning this, El-Mogy et al. [29] showed that increasing the amount of transverse reinforcement led to redistributing the moment in FRP-reinforced concrete beams. In addition to this, no significant difference was observed between the performances of beams reinforced with GFRP and steel stirrups. According to a study by Mousa [30], a satisfactory ductility response was observed for high-strength concrete beams once an appropriate amount and distribution of transverse reinforcement were chosen. The effects of transverse and flexural reinforcement and concrete strength level on the GFRP reinforced concrete beams' flexural behaviour were experimentally assessed by Khorasani and Esfahani [31] and Khorasani et al. [32]. The results showed that higher amounts of transverse reinforcement contributed to an increase in GFRP reinforced concrete beams' load-bearing capacity and a decrease in their mid-span deflection. Moreover, decreasing the diameters of tensile or transverse reinforcement and increasing their number caused to decreasing the crack widths of concrete beams. The GFRP reinforced highstrength concrete beams' ultimate load and deflection were higher than those of GFRP reinforced normal-strength concrete beams, similarly to what observed by El-Nemr et al. [33].

Generally, to get a better understanding the effect of transverse reinforcement on GFRP reinforced concrete beams' non-linear behaviour, there is a demand for developing the GFRP reinforced concrete models with different amounts of transverse reinforcement. In addition, there are few studies on the stress distribution, and failure mechanism of GFRP reinforced concrete beams with different amounts of transverse reinforcement, which can be evaluated using finite element (FE) method simulation. Furthermore, the concrete strength level influence on the nonlinear behaviour of GFRP reinforced concrete beams with different amounts of transverse reinforcement has rarely been assessed by Khorasani and Esfahani [31]. Therefore, the main 
objective of this study is to investigate the failure mechanism, mid-span deflection, load-bearing capacity, and crack widths of high- and normal-strength concrete beams reinforced with low and high flexural reinforcement ratios (GFRP bar) and different arrangements of transverse reinforcement at service and ultimate limit states using finite element (FE) method.

\section{FE modelling}

In this study, a detailed numerical analysis of the experimental results of 14 GFRP reinforced concrete beams tested by Khorasani and Esfahani [31] and Khorasani et al. [32] was developed. To simulate the FRP reinforced concrete beams and the FRP-to concrete interfaces, different software and modelling methods can be used [15,26,34-37]. In the present case, the ABAQUS software [38] was employed. This software can provide a suitable nonlinear analysis to assess the stress distribution and predict the failure mode of composite elements.

In this research, six normal-strength concrete beams $\left(\mathrm{f}^{\prime}=30 \mathrm{MPa}\right)$ with low flexural reinforcement ratio $(2 \varnothing 16$ and 5Ø10) and different transverse reinforcement $\left(\left(A_{v} / S\right)_{\text {design }}\right)$ and $2\left(A_{v} / S\right)_{\text {design }}$ ratios $)$ were modelled as presented in details in Table 1 . In addition, the same number of specimens with high flexural reinforcement ratio ( $3 \emptyset 18$ and $5 \emptyset 14)$ was developed. Therefore, the influence of low and high flexural reinforcement ratios on the flexural behaviour of concrete beams was compared to each other. It is noteworthy that GFRP bars with specific sizes were chosen based on their availability in the market. These specific sizes have been extensively tested and certified following the most important international guidelines and codes as mentioned by the manufacturer [32]. To assess the effect of concrete strength level on the behaviour of specimens, two other beams with high strength concrete $\left(f^{\prime}=\right.$ $60 \mathrm{MPa})$ and low flexural reinforcement ratio $(2 \varnothing 16$ and 5Ø10) were numerically established as well. All specimens had two longitudinal steel bars with a diameter of $12 \mathrm{~mm}$ in the compression zone. It is noteworthy that it was not possible for Khorasani et al. [32] to experimentally assess the effect of GFRP transverse reinforcement on the behaviour of concrete beams. The reason is that GFRP bars are not bendable and can only make GFRP stirrups by the manufacturers as described by Khorasani et al. [32]. Therefore, they only used the steel transverse reinforcement to prepare experimental specimens. The diameter of the transverse reinforcement was considered equal to $10 \mathrm{~mm}$ for all specimens. Reinforcing bars details and geometric characteristics of GFRP reinforced concrete beams are shown in Fig. 1. 
Table 1. Details of GFRP reinforced concrete

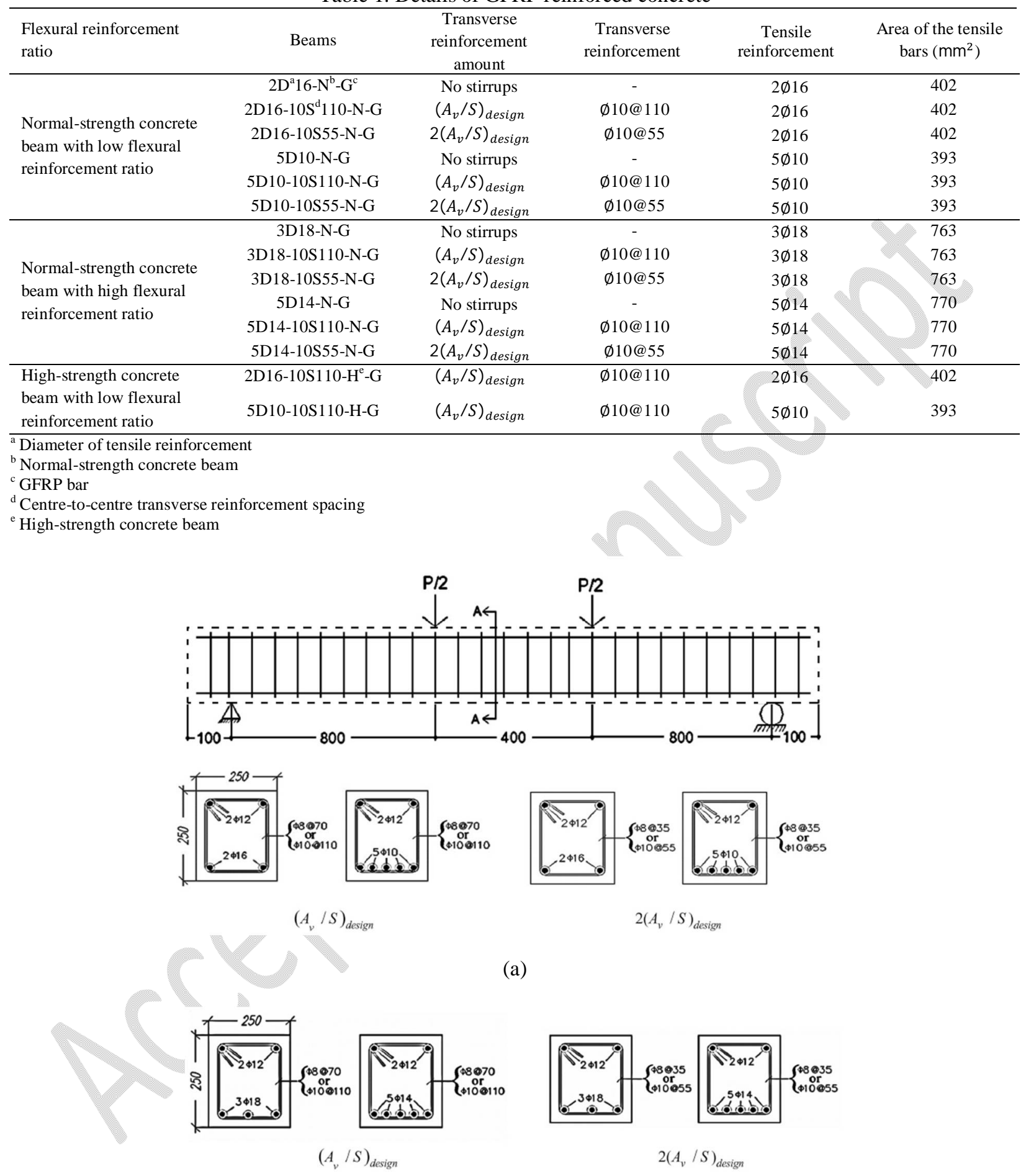

(b) 


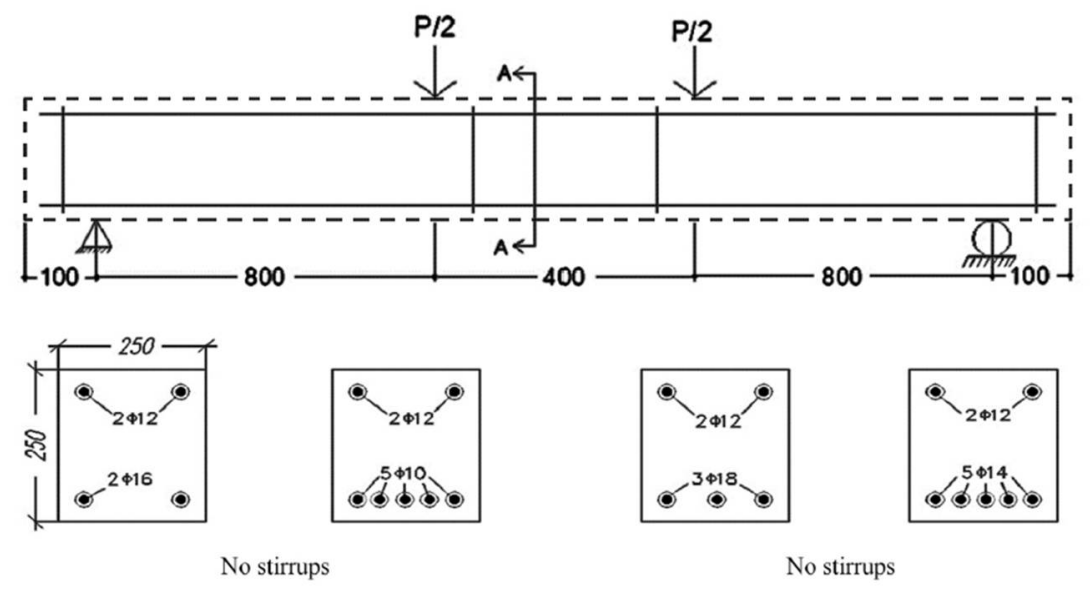

(c)

(d)

Fig. 1. Loading arrangement, geometric characteristics, and reinforcing bars details of reinforced concrete beams: with stirrups and low flexural reinforcement ratio (a); with stirrups and high flexural reinforcement ratio (b); without stirrups and low flexural reinforcement ratio (c); without stirrups and high flexural reinforcement ratio (a);

(dimensions are in $\mathrm{mm}$ )

\subsection{Material properties}

Table 2 presents the GFRP and steel bars' mechanical properties as reported by Khorasani et al. [32]. Four different sizes of GFRP bars $(10 \mathrm{~mm}, 14 \mathrm{~mm}, 16 \mathrm{~mm}$, and $18 \mathrm{~mm})$ as flexural reinforcements were introduced to the numerical models. According to the ASTM D638 [39], there was no evidence to appear the yield stress for GFRP under the standard test method; therefore, only ultimate stress was considered for the GFRP bars. As given by Khorasani et al. [32], the GFRP bars' modulus of elasticity was in the 42-46 GPa range. The corresponding range for steel bars was 201-210 GPa. In addition to this, the ultimate strain of steel bar was in the 12.44-16.45 \% range. This range for GFRP bars was 1.71-1.99 \% as presented by Khorasani and Esfahani [31].

Table 2. Mechanical properties of GFRP and steel bars

\begin{tabular}{ccccccc}
\hline $\begin{array}{c}\text { Type of } \\
\text { the bar }\end{array}$ & $\begin{array}{c}\text { Diameter } \\
(\mathrm{mm})\end{array}$ & $\begin{array}{c}\text { Area } \\
\left(\mathrm{mm}^{2}\right)\end{array}$ & $\begin{array}{c}\text { Yield stress } \\
(\mathrm{MPa})\end{array}$ & $\begin{array}{c}\text { Ultimate stress } \\
(\mathrm{MPa})\end{array}$ & $\begin{array}{c}\text { Modulus of elasticity } \\
(\mathrm{GPa})\end{array}$ & $\begin{array}{c}\text { Ultimate } \\
\text { strain }(\%)\end{array}$ \\
\hline \multirow{2}{*}{ Steel } & 12 & 113 & 412 & 682 & 210 & 12.4 \\
& 10 & 78.5 & 462 & 622 & 201 & 12.2 \\
\hline & 18 & 254 & - & 800 & 42 & 1.71 \\
GFRP & 16 & 200 & - & 775 & 46 & 1.8 \\
& 14 & 153 & - & 825 & 45 & 1.99 \\
& 10 & 78.5 & - & 789 & 44 & 1.8 \\
\hline
\end{tabular}

The ultimate strain in concrete was 0.0035 as given by Khorasani and Esfahani [31]. The initial modulus of elasticity of concrete $\left(E_{c}\right)$ was obtained using Eq. (1). 
$E_{c}=4700 \sqrt{f_{c}^{\prime}}$

Where $f_{c}^{\prime}$ and $E_{c}$ were in MPa.

The yield strain, $\varepsilon_{0}$, (unitless) corresponding to the maximum stress of concrete $\left(f_{c}^{\prime}\right)$ was calculated using Eq. (2):

$\varepsilon_{0}=\frac{1.8 f_{c}^{\prime}}{E_{c}}$

To obtain stress-strain curves of normal- and high-strength concrete (Fig. 2), the modified Hognestad formulation [40] was used (Eq. (3)):

$f_{c}=f_{c}^{\prime}\left[\frac{2 \varepsilon_{c}}{\varepsilon_{0}}-\left(\frac{\varepsilon_{c}}{\varepsilon_{0}}\right)^{2}\right]$

Where $f_{c}$ is stress in the concrete (MPa) and $\varepsilon_{c}$ is strain in the concrete (unitless).

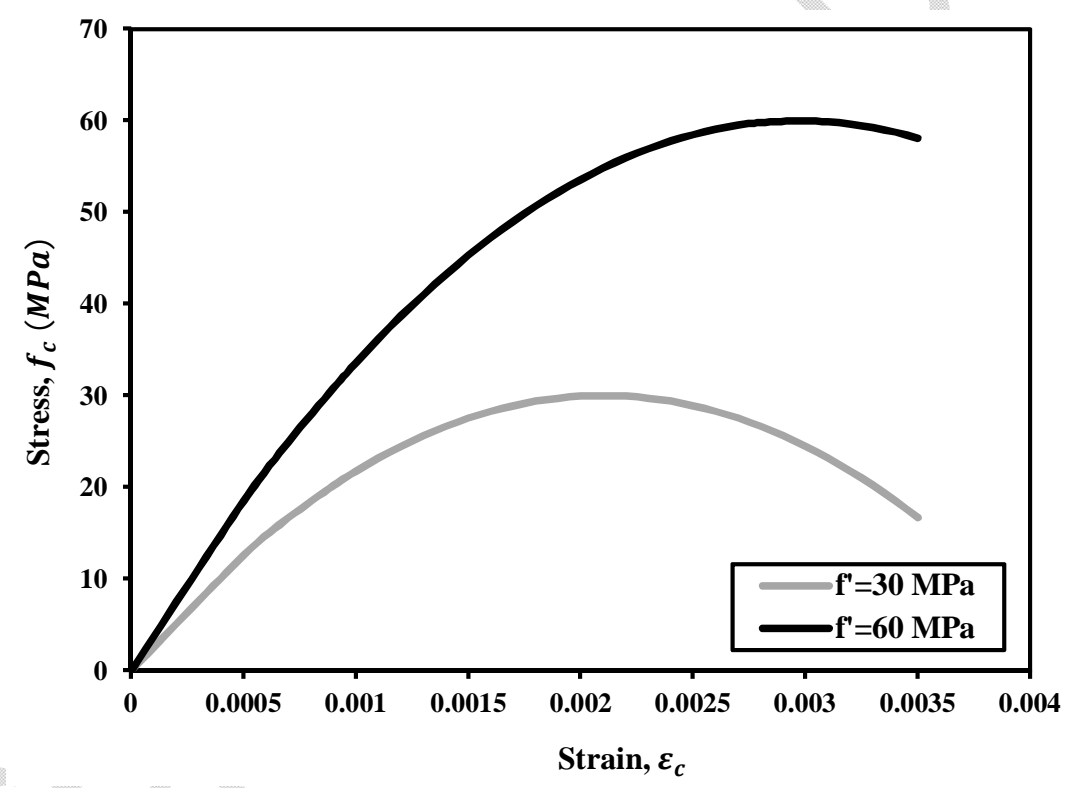

Fig. 2. Stress-strain curves of normal- and high-strength concrete.

\subsubsection{Developing the material model using Concrete Damaged Plasticity}

In ABAQUS software, to procure the stress distribution and crack propagation for the concrete component of GFRP reinforced concrete beams, three crack models are available, namely brittle cracking, concrete smeared cracking, and concrete damaged plasticity [38,41]. Due to the capability of concrete damaged plasticity (CDP) model to correspond to both nonlinear compressive and tensile behaviours of concrete elements (Fig. 3) [42], it was used in this 
study in which the relationships between the stress and strain of concrete at tension and compression can be defined using Eqs. (4) and (5), respectively:

$$
\begin{aligned}
& \sigma_{\mathrm{t}}=\left(1-\mathrm{d}_{\mathrm{t}}\right) \mathrm{E}_{\mathrm{o}}\left(\varepsilon_{\mathrm{t}}-\varepsilon_{\mathrm{t}}^{\mathrm{pl}}\right) \\
& \sigma_{\mathrm{c}}=\left(1-\mathrm{d}_{\mathrm{c}}\right) \mathrm{E}_{\mathrm{o}}\left(\varepsilon_{\mathrm{c}}-\varepsilon_{\mathrm{c}}^{\mathrm{pl}}\right)
\end{aligned}
$$

In which the equivalent plastic strains at tension and compression are represented by $\varepsilon_{\mathrm{t}}^{\mathrm{pl}}$ and $\varepsilon_{\mathrm{c}}^{\mathrm{pl}}$, respectively, Young's modulus of concrete is represented by $\mathrm{E}_{0}$, and compressive damage variable (DAMAGEC) and tensile damage variable (DAMAGET) are represented by $d_{c}$ and $d_{t}$, respectively [43].

To develop the CDP model, it is required to assume some parameters in ABAQUS software. $\mathrm{K}_{\mathrm{c}}$ is one of these parameters, which represents the deviatoric plane's modification coefficient. To derive the yielding pattern for stress-strain curves of concrete, the Drucker-Prager yield criterion can be assumed in which $\mathrm{K}_{\mathrm{c}}$ controls the failure surface in the deviatoric cross-section [44]. As depicted in Fig. 4, this surface is not required to be a perfect circle. As mentioned by other researchers $[3,35,38], \mathrm{K}_{\mathrm{c}}$ is the ratio of the second stress invariant on the tensile meridian to the compressive meridian at initial yield with a default value of 0.677 . This value was assumed for $\mathrm{K}_{\mathrm{c}}$ in this study, similar to what was considered in other research works $[3,35,45]$. Another parameter in the CDP model is the flow potential eccentricity $(\varepsilon)$, representing the ratio of tensile to compressive strength. The default value of 0.1 was assumed for $\varepsilon$ in this study as recommended by other researchers $[3,42]$. The ratio of initial biaxial compressive yield stress to initial uniaxial compressive yield stress is represented by $\sigma_{\mathrm{b} 0} / \sigma_{\mathrm{c} 0}$, which was assumed to be 1.16 according to the ABAQUS user's manual [38]. The parameter of dilation angle $(\psi)$ is introduced to determine the behaviour of concrete under confined stress. This parameter was considered equal to 31 degrees in the present study as suggested by Michał and Andrzej [46]. Another parameter is the viscosity parameter $(\mu)$, permitting to moderately exceed the plastic potential surface area in certain sufficiently small problem steps. Therefore, it is required to match the viscosity parameter value a few times to determine how big an effect it has on the problemsolution result in ABAQUS and to select an appropriate minimum amount of $\mu$ [47]. Following this, a very small number (0.0001) was considered for $\mu$ as recommended by other researchers $[3,42]$. 


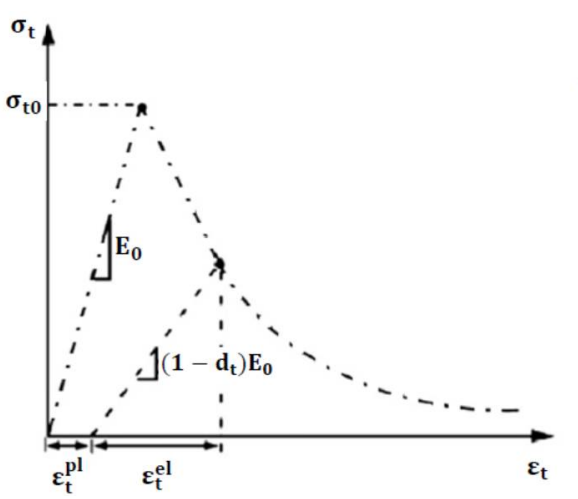

(a)

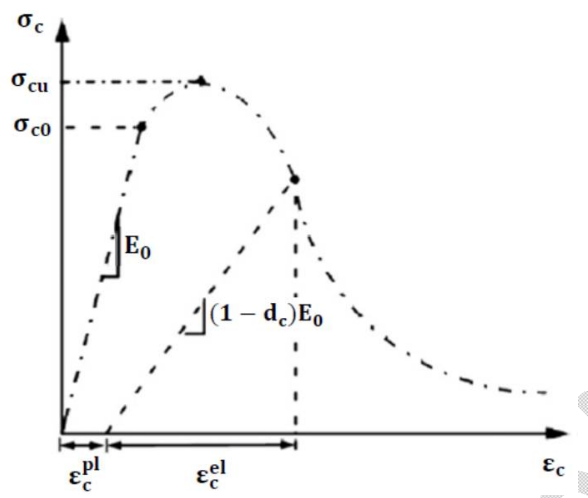

(b)

Fig. 3. Proposed non-linear tensile (a) and compressive (b) behaviours of concrete component, employed in ABAQUS

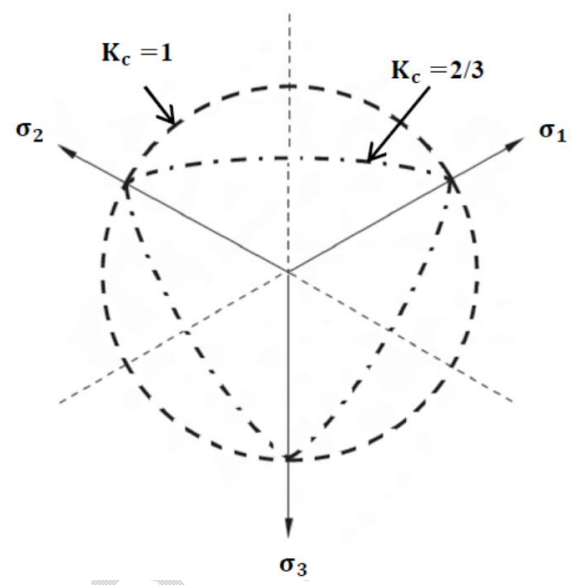

Fig. 4. Yield surfaces in the deviatoric plane, corresponding to different values of $\mathrm{K}_{\mathrm{c}}$

\subsection{Element types and features of GFRP reinforced concrete models}

For numerical simulation, the load cells and supports were considered to be rigid sections as shown in Fig. 5. The element type of these sections and concrete beam were assumed to be threedimensional (3D) hexahedral element including 8 nodes and reduced integration (C3D8R), as recommended by other researchers [48-50]. 3D deformable wire element, prepared in ABAQUS package, was used for modelling stirrups, GFRP and steel bars (Fig. 6). Two types of transverse reinforcement arrangement with the amount of $\left(A_{v} / S\right)_{\text {design }}$ and $2\left(A_{v} / S\right)_{\text {design }}$ ratios were created in numerical models as indicated in Figs. 6 (a) and 6 (b).

Suitable mesh sizes should be considered for the GFRP reinforced concrete models to predict the load vs. mid-span deflection curves of the experimental specimens. To achieve the intended mesh sizes for longitudinal GFRP and steel bars and concrete beams, different element mesh 
sizes were numerically checked and then, the approximate sizes of $35,50,45,35,45,45,25,40$, $45,25,35,45,50$, and $45 \mathrm{~mm}$ were introduced in the longitudinal direction to 2D16-N-G, 2D1610S110-N-G, 2D16-10S55-N-G, 5D10-N-G, 5D10-10S110-N-G, 5D10-10S55-N-G, 3D18-N-G, 3D18-10S110-N-G，3D18-10S55-N-G，5D14-N-G，5D14-10S110-N-G，5D14-10S55-N-G， 2D16-10S110-H-G, and 5D10-10S110-H-G, respectively. The approximate element mesh size of transverse reinforcement for all specimens was $50 \mathrm{~mm}$.

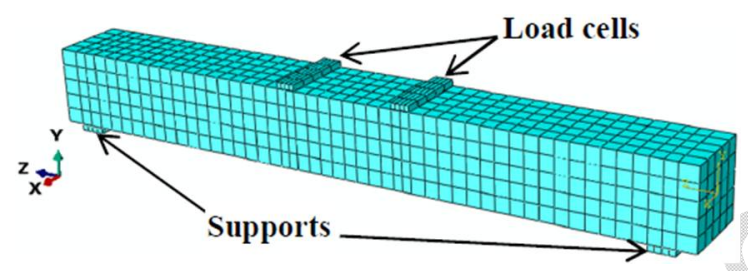

Fig. 5. FE mesh of GFRP reinforced concrete

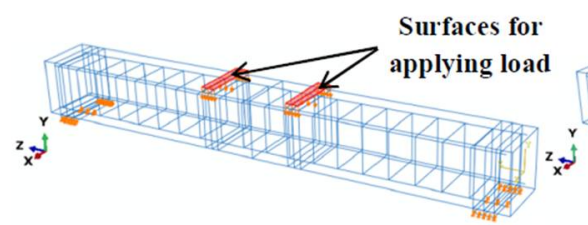

(a)

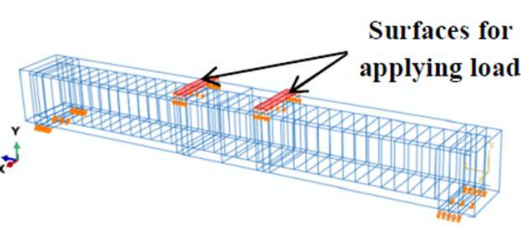

(b)

Fig. 6. Configuration of the developed concrete beams reinforced with $\left(A_{v} / S\right)_{\text {design }}(a)$; and $2\left(A_{v} / S\right)_{\text {design }}(b)$ ratios

\subsection{Boundary condition and details of surface interactions}

For numerical modelling of specimens, the tie constraint, available in ABAQUS software, was introduced between two surfaces of the GFRP reinforced concrete beam and load cells. The surface to surface contact was introduced to the interaction between the GFRP reinforced concrete beam and supports in which no slip occurred, while nodes were in contact [51]. The perfect bond was numerically considered between the reinforcement and concrete component. The surfaces of load cells, used for applying the load, are shown in Fig. 6. The displacements and rotations of supports were restricted to realistically simulate experimental conditions in numerical models.

\section{Results and discussions on FE analysis}

\subsection{Comparison between the experimental and modelling outputs}


To validate the numerical outputs with experimental results on a real scale, the reinforced concrete beams were simulated and calibrated by experimental specimens. For this purpose, the experimental outputs presented by Khorasani and Esfahani [31] and Khorasani et al. [32] were used. Figs. 7 and 8 show the plots of load against mid-span deflection to compare numerical and experimental results. At the beginning of loading, the curve slopes of numerical outputs were found to be slightly higher than those of experimental results. It seems that the numerical models' initial stiffness led to the generation of this minor difference at the beginning of loading. However, the general trends of numerical curves were nearly found to be similar to those of experimental curves and the initial minor difference between curve slopes of experimental and numerical results was negligible. Therefore, the experimental specimens' behaviour was effectively predicted by the created numerical models.

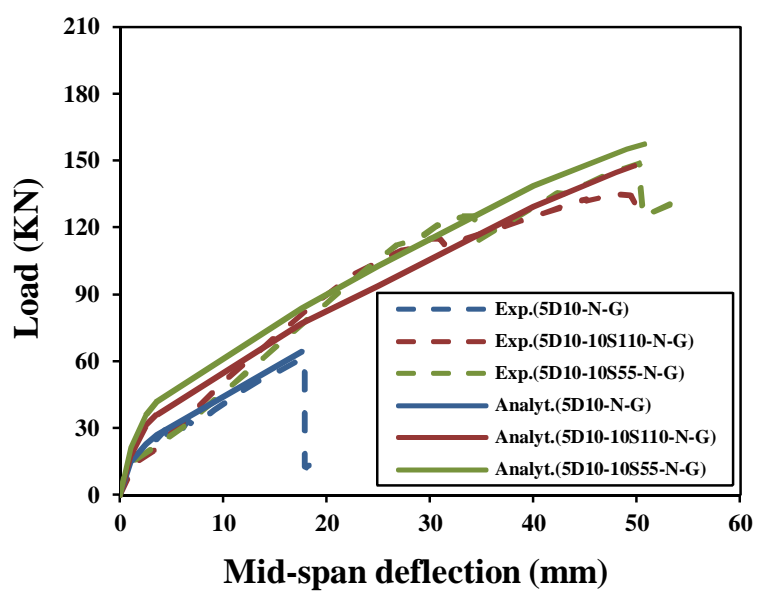

(a)

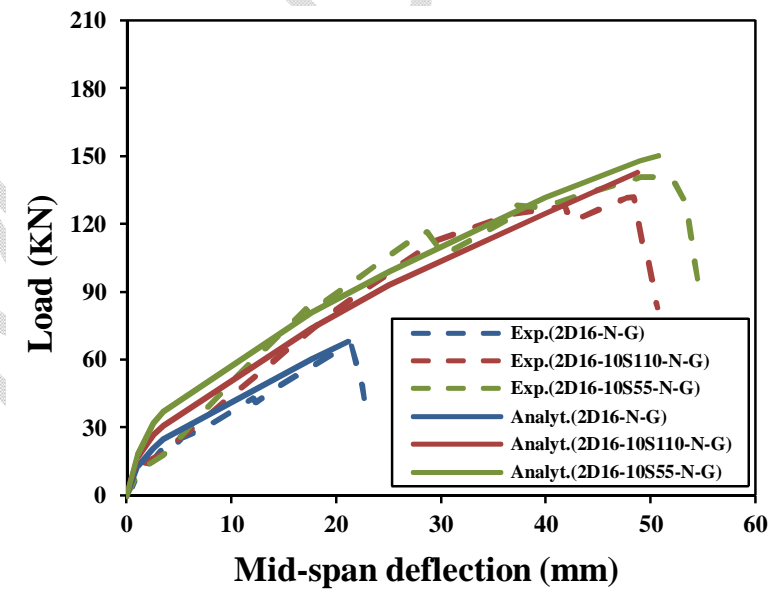

(b)

Fig. 7. Load vs. mid-span deflection plots for experimental specimens [32] and numerical models with normal strength concrete and low flexural reinforcement ratio: when using GFRP bars with the diameters of $10 \mathrm{~mm}$ (a); 


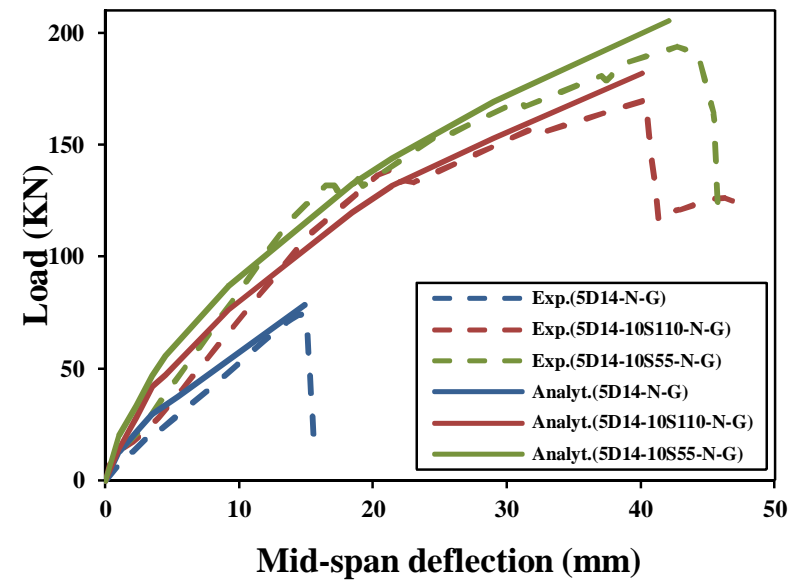

(a)

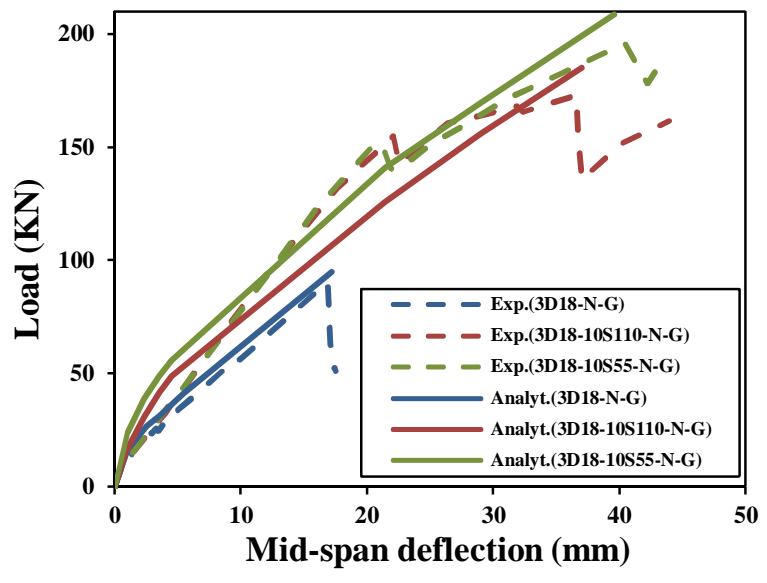

(b)

Fig. 8. Load vs. mid-span deflection plots for experimental specimens [32] and numerical models with normal strength concrete and high flexural reinforcement ratio: when using GFRP bars with the diameters of 14mm (a); $18 \mathrm{~mm}(\mathrm{~b})$

The outputs of GFRP reinforced concrete models with different amounts of transverse flexural reinforcement ratios were numerically analysed, where the concrete's strength level effect on the flexural behaviour of models was evaluated. As shown in Figs. 7 and 8, there was no significant difference between the experimental beams' mid-span deflections and those of numerical models. Meanwhile, the results of numerical models and experimental specimens are presented in Table 3, where the experimental-to-predicted load ratios for 2D16-N-G , 2D1610S110-N-G, 2D16-10S55-N-G, 5D10-N-G, 5D10-10S110-N-G, 5D10-10S55-N-G, 3D18-N-G, 3D18-10S110-N-G, 3D18-10S55-N-G, 5D14-N-G, 5D14-10S110-N-G, 5D14-10S55-N-G were obtained $0.97,1.08,0.94,0.96,0.92,0.95,0.95,0.94,0.94,0.93,0.94$, and 0.95 , respectively. The mean value of the ratios above was 0.96 , which was close to 1 . The coefficient of variation was in the 0-12.5\% range and its average value was $2.69 \%$, indicating an adequate accuracy of the models to predict the experimental specimens' flexural behaviour.

According to the experimental and numerical outputs (Table 3), the maximum and minimum ultimate loads were obtained for 3D18-10S55-N-G and 5D10-N-G, respectively. For instance, the ultimate load of 3D18-10S55-N-G model (208.9 kN) was 3.25 times more than that of 2D1610S110-N-G model $(64.3 \mathrm{kN})$. This value for the experimental specimens was attained 3.12 times. Moreover, the ultimate load of numerical models with transverse reinforcement was 1.952.62 times more than that of models without transverse reinforcement. The corresponding value 
for experimental specimens was 1.91-2.67 times. Therefore, the use of transverse reinforcement remarkably affected the ultimate load of numerical models and experimental specimens.

Since the amount and arrangement of transverse and flexural reinforcement can have an effective role in the GFRP reinforced concrete beams' flexural behaviour, the load-bearing capacity, failure mechanism, mid-span deflection, and crack width were assessed in the following to provide more explanations about the stress distribution in created models at service and ultimate loads.

Table 3. Ultimate loads of numerical models and experimental specimens

\begin{tabular}{ccccc}
\hline \multirow{2}{*}{ Beams } & \multicolumn{2}{c}{ Ultimate loads $(\mathrm{kN})$} & $\begin{array}{c}\text { Experimental- } \\
\text { to-predicted } \\
\text { load ratio }\end{array}$ & $\begin{array}{c}\text { Coefficient of variation: } \\
\text { Standard deviation }\end{array}$ \\
\cline { 2 - 4 } & $\begin{array}{c}\text { Experimental } \\
\text { specimens }\end{array}$ & $\begin{array}{c}\text { Numerical } \\
\text { models }\end{array}$ & 68 & 0.97 \\
2D16-N-G & 66.1 & 142.7 & 1.08 & 1.04 \\
2D16-10S110-N-G & 132 & 150.2 & 0.94 & 12.5 \\
2D16-10S55-N-G & 141 & 64.3 & 0.96 & 2.08 \\
5D10-N-G & 61.5 & 147.9 & 0.92 & 0 \\
5D10-10S110-N-G & 135 & 157.4 & 0.95 & 4.17 \\
5D10-10S55-N-G & 149 & 95.1 & 0.95 & 1.04 \\
\hline 3D18-N-G & 90.4 & 185.1 & 0.94 & 1.04 \\
3D18-10S110-N-G & 173 & 208.9 & 0.94 & 2.08 \\
3D18-10S55-N-G & 196 & 78.4 & 0.93 & 2.08 \\
5D14-N-G & 72.6 & 182.1 & 0.94 & 3.13 \\
5D14-10S110-N-G & 170 & 205.3 & 0.95 & 2.08 \\
5D14-10S55-N-G & 194 & & & 1.04 \\
\hline
\end{tabular}

\subsection{Transverse reinforcement effect on GFRP reinforced concrete beams' failure mechanism}

The failure mode and damage evolution of numerical models were numerically predicted using the contour plots of tensile damage variable (e.g. Fig. 9) and the failure points were determined at the end of the loading process. As shown in Fig. 9, the evolution of damage showed that the failure mechanism of GFRP reinforced concrete beam reinforced with transverse reinforcement included tensile cracking in numerical models and the failure mode was flexural. Besides, the created numerical models efficiently predicted the tensile damage propagation nearly in the same locations as revealed in the experimental outputs. Moreover, the contour plots 
of tensile damage variable (DAMAGET) demonstrated that tensile cracks were initially generated in the GFRP reinforced concrete beam' bottom in the model. Then, they extended up to the top level of concrete beams, similarly to what occurred for the experimental specimen as shown in Fig. 9.

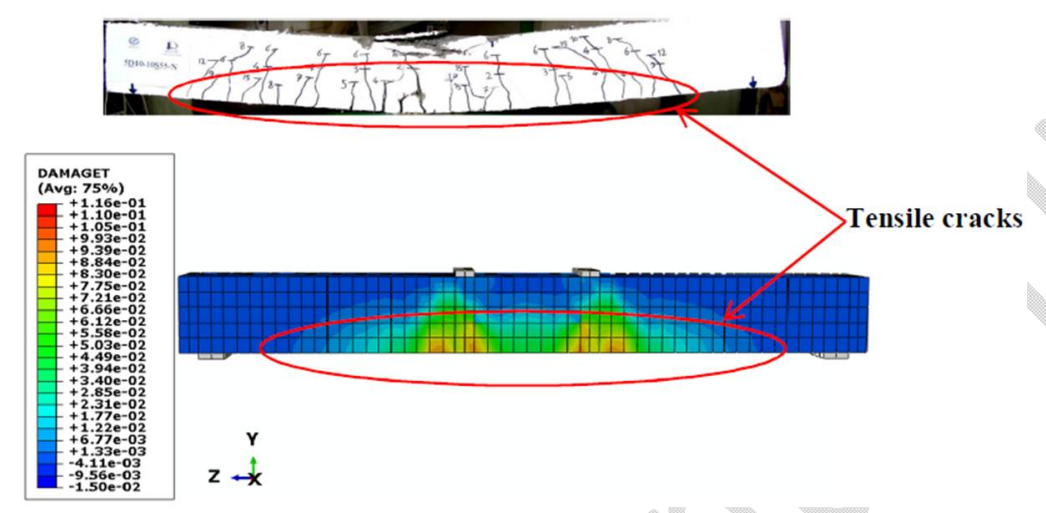

Fig. 9. Failure appearance in the experimental specimen [32] and the numerical model reinforced with the transverse reinforcement (3D18-10S110-N-G).

As briefly mentioned by Khorasani and Esfahani [31] and Khorasani et al. [32], the failure mode of GFRP reinforced concrete beams without and with transverse reinforcement was the shear failure, and concrete crushing, respectively. The use of transverse reinforcement caused to decrease the reinforced concrete beams' crack widths. However, further investigations are needed to get a better understanding of the failure mechanisms of GFRP reinforced concrete beams with and without transverse reinforcement. In the uncracked phase and in the flexural cracking stage, since the stiffness of transverse reinforcement was remarkably lower than that of the surrounding concrete, the former was not able to cross the cracks and therefore, it couldn't participated in increasing the load-bearing capacity of the concrete beams, similarly to what Mihaylov [52] described. Later on, as shown in Fig. 10, the tooth region as a cantilever fixed, between two flexural cracks was generated for the reinforced concrete beams with and without transverse reinforcement, where the bond forced between the bottom reinforcement and the concrete was prone to bend the cantilever toward the mid-span, while the aggregate interlock and dowel action resisted this bending as explained by other researchers [46-48]. After failing the tooth region for the reinforced concrete beams without transverse reinforcement, the arch action mechanism caused to generate a diagonal cracking as depicted in Fig. 10 (a). However, for the 
reinforced concrete beam with transverse reinforcement, stirrups effectively participated in increasing the load-bearing capacity once the tooth region started to fail as described by Mihaylov et al. [55]. Concerning this, the truss action mechanism caused the vertical cracks to turn towards the loading plate and it led to the generation of the diagonal compression in the cracked concrete and tension in the transverse reinforcement. Then, the secondary cracks were generated as shown in Fig. 10 (b). Indeed, the tension in the longitudinal reinforcement decreased beyond the failed concrete cantilever. Therefore, the tooth failure was delayed by the truss action mechanism and it was generated more gradually through the beam length in the presence of transverse reinforcement [52]. That's why the crack widths decreased and loadbearing capacity increased with the presence of transverse reinforcement.

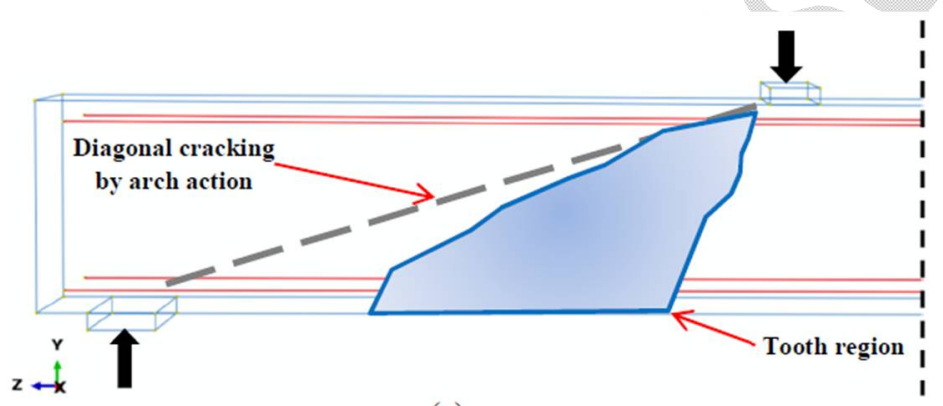

(a)

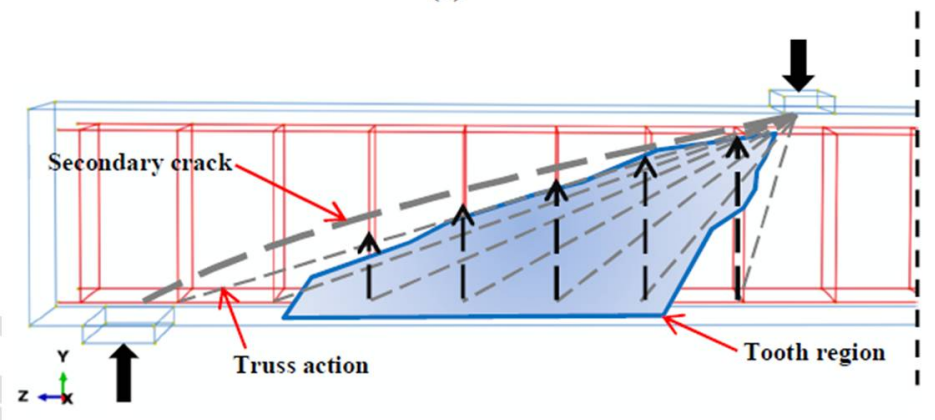

(b)

Fig. 10. Schematic representation of the arch action mechanism in the reinforced concrete beam without transverse reinforcement (a); and the truss action mechanism in the reinforced concrete beam with transverse reinforcement (b).

\subsection{Effects of transverse and flexural reinforcement on stress distribution, mid-span deflection, and crack width}

To better understand the GFRP reinforced concrete beams' non-linear behaviour, the stress distribution and load-bearing capacity of specimens were analysed in two steps including the service and ultimate loads. As per the recommendations of other researchers [56,57], the 
maximum principal stress and von Mises stress are suitable to analyse the behaviour of brittle and ductile materials, respectively. Therefore, in this study, the non-linear behaviour of the concrete beam and reinforcement component was assessed using the contour plots of maximum principal stress and the von Mises stress, respectively. For instance, the results of stress distribution for normal-strength concrete beams reinforced with GFRP bars with diameters of 16 $\mathrm{mm}$ are shown in Figs. 11-13.

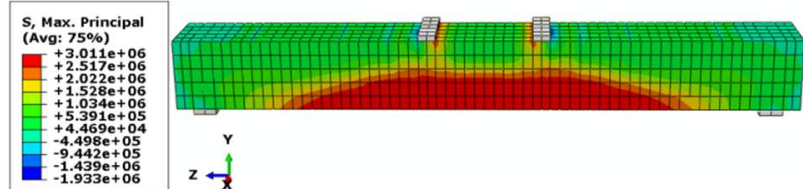

(a)

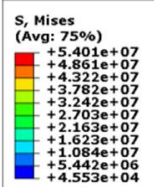

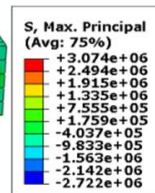

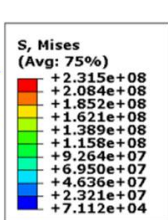

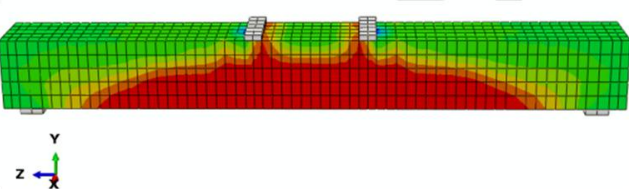

(b)

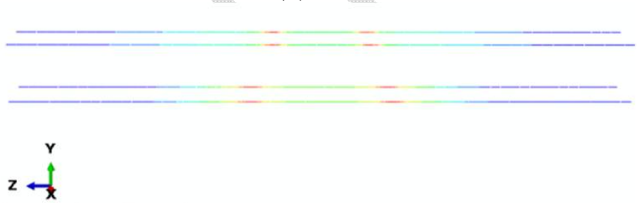

(d)

Fig. 11. Stress distribution in 2D16-N-G: for the concrete component at service load (a); and ultimate load (b); for the reinforcement components at service load (c); and ultimate load (d); the unit in the legends is MPa.

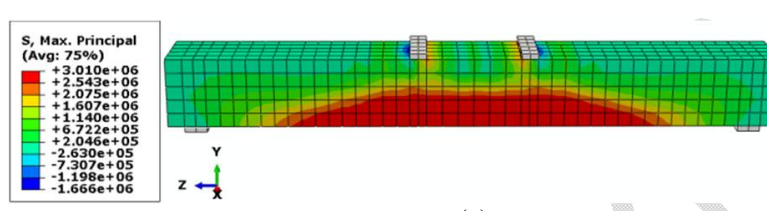

(a)

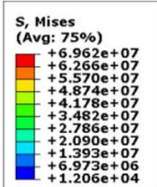

$+6.9735+06$
$+1.206 e+04$

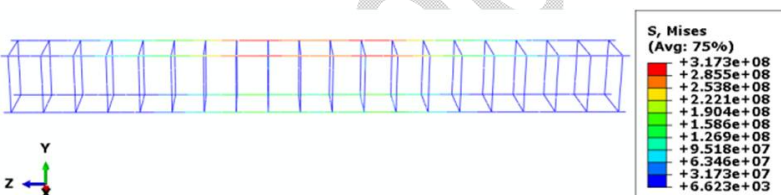

(c)
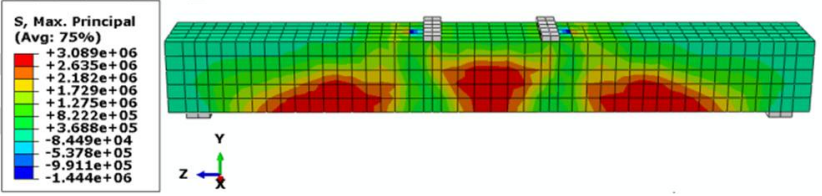

(b)

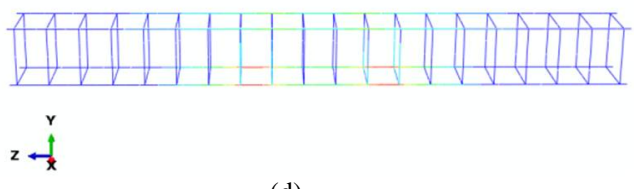

Fig. 12. Stress distribution in 2D16-10S110-N-G: for the concrete component at service load (a); and ultimate load (b); for the reinforcement components at service load (c); and ultimate load (d)

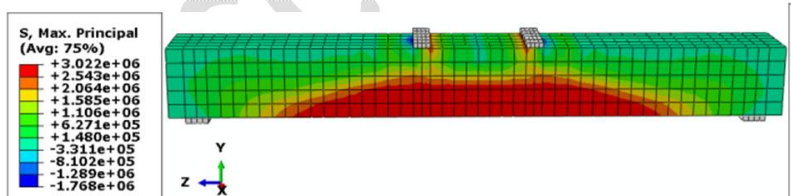

(a)

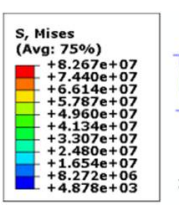
$z+\frac{1}{x}$

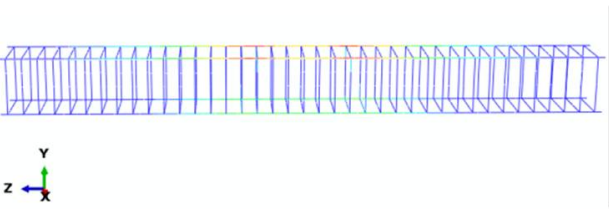

(c)

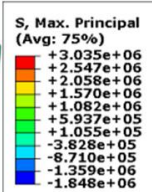

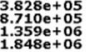
$z \stackrel{+}{\leftarrow}$

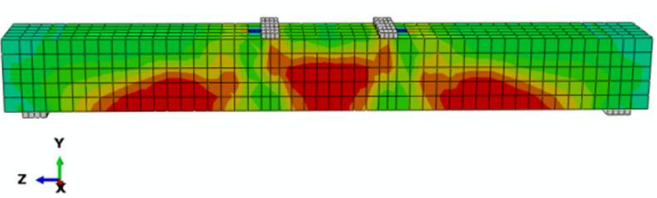

(b)
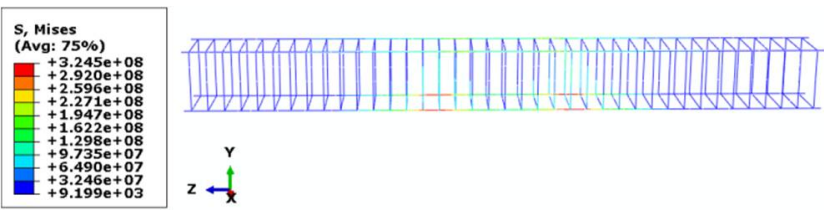

Fig. 13. Stress distribution in 2D16-10S55-N-G: for the concrete component at service load (a); and ultimate load (b); for the reinforcement components at service load (c); and ultimate load (d); the unit in the legends is MPa. 
According to the results, the highest tensile stress in concrete component for all specimens was $3 \mathrm{MPa}$ and no noticeable difference was observed between the highest amount of stress at service and ultimate loads. The stress distribution of concrete beams demonstrated that the highest stress intensities occurred in the bottom of concrete beams at service load for all specimens with different arrangements and amounts of reinforcement as seen in Figs. 11(a) and 12(a). By increasing the force up to the ultimate load, there were some differences in the evolution of stress distribution in concrete beams. The results showed that the transverse reinforcement led to propagating some parts of high-stress intensities near to the supports up to the ultimate load (Figs. 12(a) and 13(a)), while no noticeable difference was observed between the stress propagation of specimens with no transverse reinforcement at service and ultimate loads (Fig. 11(a)). Since the Young's modulus and elastic coefficient of flexural GFRP bars are low [17,58] and concrete has low tensile strength, classifying as a brittle material [59-65]; therefore, suitable arrangement and type of transverse reinforcement should be used in concrete elements to distribute the highest stress intensities in the longitudinal direction of concrete beams by increasing the force up to the ultimate load so that the sides of concrete beam can participate in carrying some of the applied load to the entire specimen.

Comparing the stress distribution in Figs. 12(b) and 13(b), the numerical outputs revealed the highest stress intensity was slightly propagated more, once the transverse reinforcement amount increased. Therefore, more parts of concrete beam participated in carrying the generated stresses, leading to decreasing the mid-span deflection and generating smaller crack widths, particularly in specimens with higher amounts of transverse reinforcement $\left(2\left(\mathrm{~A}_{\mathrm{V}} / \mathrm{S}\right)_{\text {design }}\right.$ ratio $)$ as observed by Khorasani et al. [32]. This issue could be due to the truss action mechanism causing the vertical cracks to turn towards the loading and generating the diagonal compression in the cracked concrete and tension in the transverse reinforcement (Fig. 10(a)). This in turn was associated with a subsequent participation of more parts of concrete beam in carrying the generated stresses. However, the arch action mechanism in the absence of transverse reinforcement created a diagonal cracking in the reinforced beam, resulted in increasing the midspan deflection (Fig. 10(b)), similarly to what Mihaylov et al. [52,55] observed.

Since the presence of reinforcement can affect the GFRP reinforced concrete beams' nonlinear behaviour, the results of stress distribution in longitudinal bars and stirrups are provided in 
this study. Generally, the stress of reinforcement for all specimens increased by increasing the amount of transverse reinforcement, particularly at ultimate load. For instance, the highest stress intensity of reinforcement for 2D16-N-G, 2D16-10S110-N-G, and 2D16-10S55-N-G at service load was equal to $54,69.6$, and $62.7 \mathrm{MPa}$, respectively. The corresponding values at ultimate load were $231.5,317.3$, and $325 \mathrm{MPa}$. So, the ratio of high-stress intensity under ultimate load to that under service load was found to be equal to 4.29, 4.55, and 5.18 for 2D16-N-G, 2D1610S110-N-G, and 2D16-10S55-N-G, respectively. This showed that the highest stress intensity at ultimate load increased more compared to that at service load, once transverse reinforcement amount increased. Besides, it can be stated that the transverse reinforcement effectively transferred the stresses, generated in the concrete beams, to the flexural reinforcement, by distributing the internal forces through the tooth region (Fig. 10 (b)) once the aggregate interlock and dowel action resisted the bond forced between the bottom reinforcement and the concrete [52-54]. This was associated with a subsequent decrease in mid-span deflection and crack widths, particularly for concrete beams reinforced with high flexural reinforcement ratio of

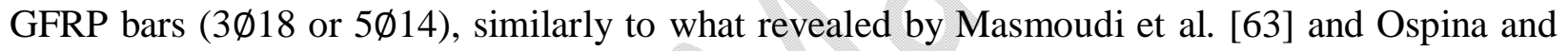
Bakis [20] for concrete beam reinforced with FRP and CFRP bars.

For all specimens with no transverse reinforcement at service load, the highest stress intensity appeared in two longitudinal steel bars as illustrated in Fig. 11(c) for 2D16-N-G. The concentration of the highest amount of stress intensity decreased in these two steel bars by the presence of transverse reinforcement and it seems that GFRP flexural bars moderately got involved in bearing some of the generated stress intensity. This participation increased by increasing the amount of transverse reinforcement at service load as shown in Figs. 12(c) and 13(c). At ultimate load, for all specimens with no transverse reinforcement, the highest stress intensity was observed in both longitudinal steel and GFRP bars as shown for the 2D16-N-G in Fig. 11(d). The presence of transverse reinforcement led to concentrating all the highest stress intensity on GFRP bars as shown in Figs. 12(d) and 13(d).

To compare the stress distribution in concrete beam and GFRP bars with presence of transverse reinforcement at ultimate load, it can be stated that there was no evidence to appear the highest tensile stress in some parts, near to the bottom of concrete beam, while GFRP bars bore the highest stress intensity in the same locations as shown in Figs. 13 (b) and 13 (d) for 2D16-10S55-N-G. This matter showed that the transverse reinforcement caused concrete 
component and GFRP bars to effectively collaborate for carrying the force, applied to the entire specimen.

\subsection{A comparison between normal and high-strength concrete beams reinforced with GFRP}

The stress distribution of GFRP reinforced high-strength concrete beams with the amount of transverse reinforcement of $\left(A_{v} / S\right)$ design was compared with that of GFRP reinforced normalstrength concrete beams with the same amount of transverse reinforcement. According to the experimental outputs attained by Khorasani and Esfahani [31] and Khorasani et al. [32], the ultimate loads of 2D16-10S110-H-G and 5D10-10S110-H-G were found to be $38.4 \%$ and $67.95 \%$ more than those of 2D16-10S110-N-G and 5D10-10S110-N-G, respectively (Fig. 14). These differences observed for mid-span deflection were obtained to be equal to $12.7 \%$ and $2.9 \%$.

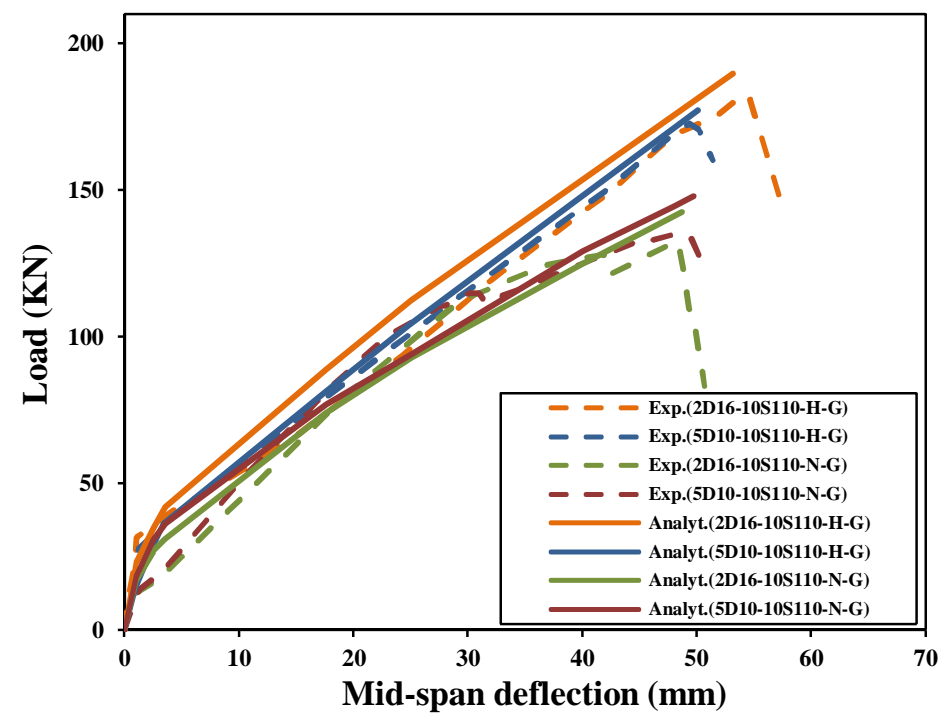

Fig. 14. Load vs. mid-span deflection plot for experimental specimens [32] and numerical models with high strength concrete and low flexural reinforcement ratio when using GFRP bars with the diameters of $16 \mathrm{~mm}$ and $10 \mathrm{~mm}$.

Therefore, increasing the concrete strength level from 30MPa to 60MPa resulted in increasing the ultimate load and mid-span deflection due to the increase in the capacity of the concrete beam, similarly to El-Nemr et al. [33] observed. They demonstrated that the strain and mid-span deflection of GFRP reinforced normal-strength concrete beam was lower than those of GFRP reinforced high-strength concrete beam. For further investigation, the stress distribution in highstrength concrete beams reinforced with GFRP flexural bars was numerically analysed as 
indicated in Fig. 15. For concrete beams reinforced with GFRP bars with the diameter of $16 \mathrm{~mm}$, at ultimate load, the highest tensile stress of flexural GFRP bars in high-strength concrete beams was found to be about 14\% higher than that in normal-strength concrete beams as shown in Figs. 12 (d) and 15 (d). This difference for concrete beams reinforced with flexural GFRP bars with the diameter of $10 \mathrm{~mm}$ was about $5 \%$. Therefore, the bond strength of GFRP bars in high-strength concrete beams was slightly higher than that in normal-concrete beam, particularly at ultimate load. In a similar study, Zemour et al. [23] showed that the bond strength of GFRP bars in the normal-concrete was moderately higher than that in self-compacting concrete beams.

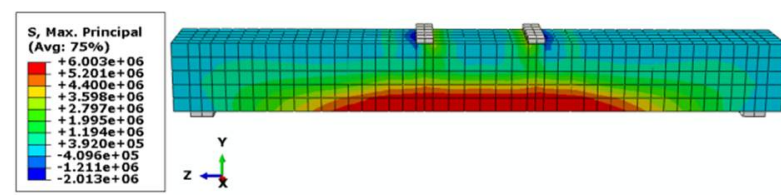

(a)
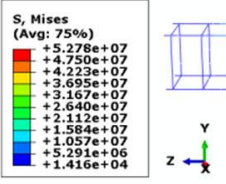

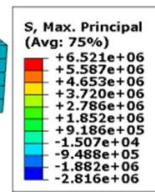

$-1.882 e+06$
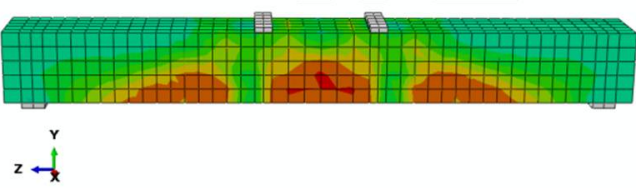

(b)

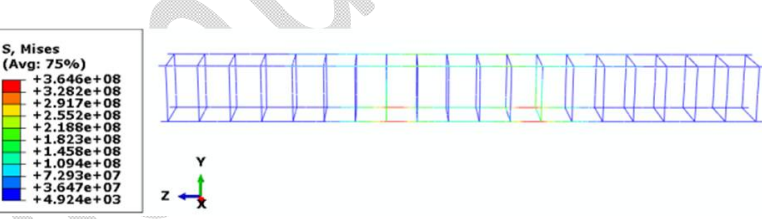

(d)

Fig. 15. Stress distribution in 2D16-10S110-H-G: for the concrete component at service load (a); and ultimate load (b); for reinforcement components at service load (c); and ultimate load (d); the unit in the legends is MPa.

At service load, the highest tensile stress of 2D16-10S110-H-G (Fig. 15 (a)) was more concentrated on the bottom of the concrete component than that of 2D16-10S110-N-G (Fig. 12 (a)). At ultimate load, this stress for 2D16-10S110-H-G (Fig. 15 (b)) was less scattered across the sides of the concrete beam than that of 2D16-10S110-N-G (Fig. 12 (b)). Generally, it can be inferred that the transverse reinforcement got involved in distributing the stress intensity in the normal-strength concrete beams more than that in the high-strength concrete beams either at service load or at ultimate load.

\section{Conclusions}

This work modelled and analysed the non-linear behaviour of GFRP reinforced concrete beams with different amounts of transverse reinforcement using the FE analyses. Based the numerical results, the main conclusions are:

- In all cases, the highest tensile stress in normal-strength concrete beams was $3 \mathrm{MPa}$ 
and this stress at service load was found to be nearly the same at ultimate load. Furthermore, for all specimens with different arrangements and amounts of reinforcement, the highest stress intensities were observed in the bottom of concrete beams at service load;

- According to the numerical results, some parts of high-stress intensities were propagated near to the supports up to the ultimate load owing to the presence of the transverse reinforcement, while the stress propagation of specimens with no transverse reinforcement at ultimate load was found to be nearly the same at service load;

- The truss action mechanism caused the vertical cracks to turn towards the loading and subsequently generated the diagonal compression in the cracked concrete and tension in the transverse reinforcement. This caused that the sides of concrete beam reinforced with transverse reinforcement effectively got involved in carrying some of the highest stresses generated by the applied load, leading to decreasing the mid-span deflection and generating smaller crack widths particularly in specimens with higher amounts of transverse reinforcement $\left(2\left(\mathrm{~A}_{\mathrm{v}} / \mathrm{S}\right)_{\text {design }}\right.$ ratio);

- The transverse reinforcement effectively transferred the stresses, generated in the concrete beams, to the flexural reinforcement, where the dowel action mechanism resisted the bond forced between the bottom reinforcement and the concrete by distributing the internal forces through the tooth region. This was associated with a subsequent decrease in mid-span deflection and crack widths;

- At service load, the highest stress intensity in specimens with no transverse reinforcement appeared to be in two longitudinal steel bars, while the presence of transverse reinforcement resulted in participating the GFRP flexural bars in bearing some of the generated highest stress intensity;

- At ultimate load, for all specimens with no transverse reinforcement, the highest stress intensity appeared to be in both longitudinal steel and GFRP bars, while the presence of transverse reinforcement caused the highest stress intensity to concentrate on GFRP bars;

- Increasing the concrete strength level from $30 \mathrm{MPa}$ to $60 \mathrm{MPa}$ led to an increase in the ultimate load and mid-span deflection of GFRP reinforced concrete beams. Furthermore, the transverse reinforcement got involved in distributing the stress 
intensity in the normal-strength concrete beams more than that in the high-strength concrete beams either at service load or at ultimate load.

- At ultimate load, for concrete beams reinforced with GFRP bars with the diameters of $16 \mathrm{~mm}$ and $10 \mathrm{~mm}$, the highest tensile stress of flexural GFRP bars in high-strength concrete beams was found to be about $14 \%$ and 5\%, respectively, higher than that in normal-strength concrete beams. Therefore, the GFRP bars' bond quality in highstrength concrete beams was moderately higher than that in the normal-concrete beam, particularly at ultimate load.

\section{References}

[1] Akbarzadeh Bengar $\mathrm{H}$, Shahmansouri A. Post-fire behavior of unconfined and steel tube confined rubberized concrete under axial compression. Structures 2021.

[2] Jafari K, Tabatabaeian M, Joshaghani A, Ozbakkaloglu T. Optimizing the mixture design of polymer concrete: An experimental investigation. Construction and Building Materials 2018;167:185-96.

[3] Madandoust R, Kazemi M, Yousefi M oghadam S. Analytical study on tensile strength of concrete. Revista Romana de Materiale 2017;2:204-9.

[4] Nematzadeh M, Karimi A, Gholampour A. Pre- and post-heating behavior of concrete-filled steel tube stub columns containing steel fiber and tire rubber. Structures 2020;27:2346-64. https://doi.org/10.1016/j.istruc.2020.07.034.

[5] Saradar A, Tahmouresi B, M ohseni E, Shadmani A. Restrained shrinkage cracking of fiberreinforced high-strength concrete. Fibers 2018;6:12.

[6] Shahmansouri AA, Nematzadeh M, Behnood A. M echanical properties of GGBFS-based geopolymer concrete incorporating natural zeolite and silica fume with an optimum design using response surface method. Journal of Building Engineering 2021;36:102138. https://doi.org/10.1016/j.jobe.2020.102138.

[7] Toufigh V, Abyaneh MJ, Jafari K. Study of Behavior of Concrete under Axial and Triaxial Compression. ACl Materials Journal 2017;114.

[8] Akbarzadeh Bengar $\mathrm{H}$, M ousavi M. Performance of an innovative anchorage system for strengthening RC beams in adjacency of columns with FRP laminates. Structures 2020;28:197-204. https://doi.org/10.1016/j.istruc.2020.08.075.

[9] Farrokh Ghatte H. Failure mechanisms and cracking performance of T-shaped SCC beam-column connections at top floor: Test results and FE modeling. Structures 2020;28:1009-18. https://doi.org/10.1016/j.istruc.2020.09.051.

[10] Khaneghahi MH, Najafabadi EP, Shoaei P, Oskouei AV. Effect of intumescent paint coating on mechanical properties of FRP bars at elevated temperature. Polymer Testing 2018;71:72-86.

[11] Shahmansouri AA, Akbarzadeh Bengar H, Jahani E. Predicting compressive strength and electrical resistivity of eco-friendly concrete containing natural zeolite via GEP algorithm. Construction and Building M aterials 2019;229:116883. https:// doi.org/10.1016/j.conbuildmat.2019.116883.

[12] Yousefi M oghadam S, Ranjbar M M , M adandoust R, Kazemi M. Analytical study on the behavior of corrosion-damaged reinforced concrete beams strengthen with FRP. Revista Romana de Materiale 2017;47:514-21.

[13] Biscaia HC, Silva MA, Chastre C. An experimental study of GFRP-to-concrete interfaces submitted to humidity cycles. Composite Structures 2014;110:354-68. 
[14] Silva MAG da, Biscaia H, Rodrigues CC. Influence of temperature cycles on bond between glass fiber-reinforced polymer and concrete. ACl Structural Journal 2013;110:977-87.

[15] Biscaia HC, Chastre C, Viegas A, Franco N. Numerical modelling of the effects of elevated service temperatures on the debonding process of FRP-to-concrete bonded joints. Composites Part B: Engineering 2015;70:64-79.

[16] Akbarzadeh Bengar H, Hosseinpour M, Celikag M. Influence of CFRP confinement on bond behavior of steel deformed bar embedded in concrete exposed to high temperature. Structures 2020;24:240-52. https:// doi.org/10.1016/j.istruc.2020.01.017.

[17] Jabbar SA, Farid SB. Replacement of steel rebars by GFRP rebars in the concrete structures. Karbala International Journal of Modern Science 2018;4:216-27.

[18] Kemp B, Blowes D. Concrete reinforcement and glass fiber reinforced polymer. Queensland Roads Edition 2011:40-8.

[19] Ashour AF. Flexural and shear capacities of concrete beams reinforced with GFRP bars. Construction and Building M aterials 2006;20:1005-15.

[20] Ospina CE, Bakis CE. Indirect flexural crack control of concrete beams and one-way slabs reinforced with FRP bars. Proceedings of FRPRCS 2007;8.

[21] Najafabadi EP, Oskouei AV, Khaneghahi MH, Shoaei P, Ozbakkaloglu T. The tensile performance of FRP bars embedded in concrete under elevated temperatures. Construction and Building Materials 2019;211:1138-52.

[22] Golafshani EM, Rahai A, Sebt MH. Bond behavior of steel and GFRP bars in self-compacting concrete. Construction and Building M aterials 2014;61:230-40.

[23] Zemour N, Asadian A, Ahmed EA, Khayat KH, Benmokrane B. Experimental study on the bond behavior of GFRP bars in normal and self-consolidating concrete. Construction and Building M aterials 2018;189:869-81.

[24] Saleh N, Ashour A, Lam D, Sheehan T. Experimental investigation of bond behaviour of two common GFRP bar types in high-Strength concrete. Construction and Building $M$ aterials 2019;201:610-22.

[25] ACl 440.1 R-03 ACl. Guide for the Design and Construction of Concrete Reinforced with FRP Bars: ACl 440.1 R-03, American Concrete Institute; 2003.

[26] Biscaia HC, Chastre C, Silva M A. M odelling GFRP-to-concrete joints with interface finite elements with rupture based on the M ohr-Coulomb criterion. Construction and Building Materials 2013;47:261-73.

[27] Biscaia HC, Silva MA, Chastre C. Factors influencing the performance of externally bonded reinforcement systems of GFRP-to-concrete interfaces. Materials and Structures 2015;48:2961-81.

[28] Newhook J, Ghali A, Tadros G. Cracking and deformability of concrete flexural sections with fiber reinforced polymer. Journal of Structural Engineering 2002;128:1195-201.

[29] El-M ogy M, El-Ragaby A, El-Salakawy E. Effect of Transverse Reinforcement on the Flexural Behavior of Continuous Concrete Beams Reinforced with FRP. Journal of Composites for Construction 2011;15:672-81. https:// doi.org/10.1061/(ASCE)CC.1943-5614.0000215.

[30] M ousa MI. Flexural behaviour and ductility of high strength concrete (HSC) beams with tension lap splice. Alexandria Engineering J ournal 2015;54:551-63. https://doi.org/10.1016/j.aej.2015.03.032.

[31] M ohtaj Khorasani AM, Esfahani MR. Effect of Concrete Strength, Arrangement/Ratio of Reinforcement on Flexural Behavior and Cracking of Concrete Beams Reinforced with GFRP Bars. Journal of Structural and Construction Engineering 2018.

[32] Khorasani AM, Esfahani M R, Sabzi J. The effect of transverse and flexural reinforcement on deflection and cracking of GFRP bar reinforced concrete beams. Composites Part B: Engineering 2019;161:530-46. 
[33] El-Nemr A, Ahmed EA, Benmokrane B. Flexural Behavior and Serviceability of Normal-and HighStrength Concrete Beams Reinforced with Glass Fiber-Reinforced Polymer Bars. ACl Structural Journal 2013;110.

[34] Biscaia HC, Chastre C, Viegas A. A new discrete method to model unidirectional FRP-to-parent material bonded joints subjected to mechanical loads. Composite Structures 2015;121:280-95.

[35] Biscaia HC, Chastre C, Silva M A. A smeared crack analysis of reinforced concrete T-beams strengthened with GFRP composites. Engineering Structures 2013;56:1346-61.

[36] Biscaia HC, M icaelo R, Teixeira J, Chastre C. Delamination process analysis of FRP-to-parent material bonded joints with and without anchorage systems using the distinct element method. Composite Structures 2014;116:104-19.

[37] Franco N, Biscaia $\mathrm{H}$, Chastre $\mathrm{C}$. Experimental and numerical analyses of flexurally-strengthened concrete T-beams with stainless steel. Engineering Structures 2018;172:981-96.

[38] Hibbitt D, Karlsson B, Sorensen P. ABAQUS/standard: User's M anual. vol. 1. Hibbitt, Karlsson \& Sorensen; 2011.

[39] ASTM D638 A. ASTM D638-14 Standard Test Methods for Tensile Properties of Plastic. America Society for Testing and Material 2014.

[40] Hognestad E. Study of combined bending and axial load in reinforced concrete members. University of Illinois at Urbana Champaign, College of Engineering ...; 1951.

[41] Kazemi M, Li J, Harehdasht SL, Yousefieh N, Jahandari S, Saberian M. Non-linear behaviour of concrete beams reinforced with GFRP and CFRP bars grouted in sleeves. Structures, vol. 23, Elsevier; 2020, p. 87-102.

[42] M adandoust R, Kazemi M . Numerical analysis of break-off test method on concrete. Construction and Building Materials 2017;151:487-93.

[43] Lee J, Fenves GL. Plastic-damage model for cyclic loading of concrete structures. Journal of Engineering M echanics 1998;124:892-900.

[44] Drucker DC, Prager W. Soil mechanics and plastic analysis or limit design. Quarterly of Applied Mathematics 1952;10:157-65.

[45] Madandoust R, Bazkiyaei ZFZ, Kazemi M. Factor influencing point load tests on concrete. Asian Journal of Civil Engineering 2018;19:937-47.

[46] M ichal S, Andrzej W. Calibration of the CDP model parameters in Abaqus. The 2015 Wourld Congress on Advances in Structural Engineering and M echanics (ASEM 15), 2015.

[47] Kmiecik P, Kamiński M. Modelling of reinforced concrete structures and composite structures with concrete strength degradation taken into consideration. Archives of Civil and M echanical Engineering 2011;11:623-36.

[48] Libecajtová A. Numerical Analysis of Compressed M asonry Columns. Periodica Polytechnica Civil Engineering 2020;64:722-30.

[49] Kazemi M, Courard L. M odelling thermal and humidity transfers within green roof systems: effect of rubber crumbs and volcanic gravel. Advances in Building Energy Research 2020;0:1-26. https://doi.org/10.1080/17512549.2020.1858961.

[50] Kazemi M, Courard L. Simulation of humidity and temperature distribution in green roof with pozzolana as drainage layer: influence of outdoor seasonal weather conditions and internal ceiling temperature. Science and Technology for the Built Environment 2021;27:509-23.

[51] Kazemi M, Kafi M A, Hajforoush M, Kheyroddin A. Cyclic behaviour of steel ring filled with compressive plastic or concrete, installed in the concentric bracing system. Asian J Civ Eng 2020;21:29-39. https:// doi.org/10.1007/s42107-019-00181-7.

[52] M ihaylov B. Behavior of Deep Reinforced Concrete Beams under M onotonic and Reversed Cyclic Load. PhD Thesis. University of Pavia, Pavia, Italy, 2008.

[53] Kani GNJ. The riddle of shear failure and its solution. Journal Proceedings, vol. 61, 1964, p. 441-68. 
[54] Kotsovos GM, Kotsovos MD. Effect of axial compression on shear capacity of linear RC members without transverse reinforcement. M agazine of Concrete Research 2013;65:1360-75.

[55] M ihaylov BI, Bentz EC, Collins M P. Behavior of Large Deep Beams Subjected to M onotonic and Reversed Cyclic Shear. ACl Structural Journal 2010;107.

[56] Džugan J, Španiel M, Prantl A, Kuželka J, M oravec M . Identification of Ductile Damage Parameters in the Abaqus. Bulletin of Applied Mechanics 2013;8:89-92.

[57] Zhang W, Subhash G. An elastic-plastic-cracking model for finite element analysis of indentation cracking in brittle materials. International J ournal of Solids and Structures 2001;38:5893-913.

[58] Yoo D-Y, Banthia N, Yoon Y-S. Predicting service deflection of ultra-high-performance fiberreinforced concrete beams reinforced with GFRP bars. Composites Part B: Engineering 2016;99:381-97. https:// doi.org/10.1016/j.compositesb.2016.06.013.

[59] Hajforoush M, M adandoust R, Kazemi M. Effects of simultaneous utilization of natural zeolite and magnetic water on engineering properties of self-compacting concrete. Asian J Civ Eng 2019;20:289-300. https:// doi.org/10.1007/s42107-018-00106-w.

[60] Jahandari S, Li J, Saberian M, Shahsavarigoughari M. Experimental study of the effects of geogrids on elasticity modulus, brittleness, strength, and stress-strain behavior of lime stabilized kaolinitic clay. GeoRes/ 2017;13:49-58. https:// doi.org/10.1016/j.grj.2017.02.001.

[61] Jafari A, Ghasemi MR, Akbarzadeh Bengar $H$, Hassani B. Seismic performance and damage incurred by monolithic concrete self-centering rocking walls under the effect of axial stress ratio. Bull Earthquake Eng 2018;16:831-58. https:// doi.org/10.1007/s10518-017-0227-2.

[62] Jafari A, Ghasemi M R, Bengar HA, Hassani B. A novel method for quantifying damage to cast-inplace self-centering concrete stepping walls. Structural Concrete 2018;19:1713-26. https://doi.org/10.1002/suco.201700247.

[63] Masmoudi R, Benmokrane B, Chaallal 0 . Cracking behaviour of concrete beams reinforced with fiber reinforced plastic rebars. Canadian Journal of Civil Engineering 2011. https:// doi.org/10.1139//96-926.

[64] Shahmansouri AA, Akbarzadeh Bengar $\mathrm{H}$, Azarij afari $\mathrm{H}$. Life cycle assessment of eco-friendly concrete mixtures incorporating natural zeolite in sulfate-aggressive environment. Construction and Building Materials 2021;268:121136. https://doi.org/10.1016/j.conbuildmat.2020.121136.

[65] M emarzadeh A, Shahmansouri AA, Nematzadeh M, Gholampour A. A review on fire resistance of steel-concrete composite slim-floor beams. Steel and Composite Structures 2021;40:13-32. 